\title{
On the Strength and Crack Propagation Process of the Pre-Cracked Rock-Like Specimens under Uniaxial Compression
}

\author{
H. Haeri, ${ }^{a, 1}$ K. Shahriar, ${ }^{b}$ M. F. Marji, ${ }^{c}$ and P. Moarefvand ${ }^{b}$ \\ ${ }^{a}$ Islamic Azad University, Tehran, Iran \\ b Amirkabir University of Technology, Tehran, Iran \\ c Yazd University, Yazd, Iran \\ ${ }^{1}$ haerihadi@gmail.com; hadihaeri@ymail.com
}

УДК 539.4

\section{О прочности и процессе роста исходных трещин в образцах из материала типа горных пород при одноосном сжатии}

\author{
Х. Хаэри, ${ }^{\mathrm{a}}$ К. Шахриар, ${ }^{\sigma}$ М. Ф. Маржи, ${ }^{\mathrm{B}}$ П. Моарефванд ${ }^{6}$ \\ а Исламский университет Азад, Тегеран, Иран \\ ${ }^{\sigma}$ Технологический университет им. Амира Кабира, Тегеран, Иран \\ в Университет г. Йезд, Иран
}

Проведены испытания на сжатие ичилинрических образиов с исходными трещчнами из материала типа горных пород (пуциолановый портландиемент). Результаты экспериментальных измерений напряжений, деформаций и характеристик прочности образцов показывают, что наличие исходных трещин и их ориентация не оказывают значительного влияния на величину предела прочности при сжатии. Исследовано зарождение и слияние трещин на стадии их роста. Прочесс разрушения образцов исследовали для случаев наличия в их ичентральной части одиночных или парных трещин, расположенных под разныли углами, и приложения одноосных сжимающих нагрузок к обоим торияам образия. На первой стадии нагружения наблюдалось возникновение стреловидных трещчин и их рост в направлении оси одноосной сжимающей нагрузки. Кроме того, для вторичных трещчин с квазикомпланарной и/или наклонной конфигурацией характерен стабильный рост. В дальнейтем эти трещины могут развиваться в направлении максимальных главных напряжений. Выполнен численный расчет образцов с трещинами с помощью непрямого метода граничных элементов, а именно: метода разрыва перемещзений. Сравнительный анализ расчетных и экспериментальных результатов подтверждает их достоверность.

Ключевые слова: образцы из материалов типа горных пород, рост трещин, слияние, экспериментальные работы, парные трещины.

Introduction. Experimental works are mainly used to study the crack propagation and crack coalescence phenomena in brittle substances such as rocks [1-5]. The pre-existing cracks in rocks are normally under compressive loading and mainly propagated in a stable manner due to formation of wing and/or secondary cracks [6]. It is mainly expected that the crack initiation will follow in the direction (approximately) parallel to the maximum compressive stress [7]. In a crack propagation process of the brittle substances such as rock-like specimens usually two types of cracks are observed originating from the original tips of pre-existing cracks (i.e., wing cracks and secondary cracks as shown in Fig. 1). Wing cracks are usually produced due to tension while secondary cracks may initiate due to 


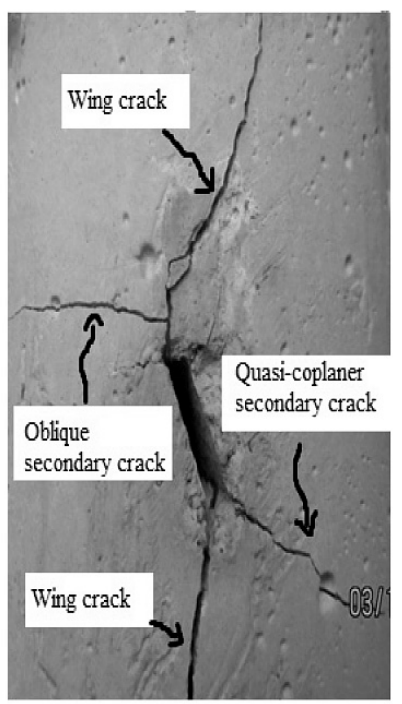

Fig. 1. A schematic view of a pre-existing crack in uniaxial compression.

shear. Therefore, initiation of wing cracks in rocks is favored relative to secondary cracks because of the lower toughness of these materials in tension than in shear [8].

Wing cracks are usually considered as the emanating tensile cracks that initiate at or near the original tips of pre-existing cracks and propagate in a curved path (with increasing load) and the secondary cracks may be considered as shear cracks that may grow from the original tips of the cracks. Secondary cracks may initiate in two different directions, coplanar (quasi-coplanar), and oblique to the pre-existing cracks $[9,10]$.

Many experimental works have been devoted to study the crack initiation, propagation, interaction and eventual coalescence of the pre-existing cracks in specimens of various substances, including natural rocks or rock-like materials under compressive loading [11-17].

Recently, Park and Bobet [18, 19] carried out compression tests on rock-like specimens with three closed cracks and compared the cracking process in specimens with open cracks. The differences between open and closed cracks with different geometries are investigated.

In another research work, Yang et al. [20] analyzed the failure mode and cracking process of marble specimens containing different pre-existing cracks under uniaxial compression, investigating the effect of crack geometry and crack coalescence on the strength and deformation behavior of marble specimens. Janeiro and Einstein [21] also conducted uniaxial compression tests to investigate the cracking behavior of prismatic gypsum specimens containing one or two inclusions. In addition, Yang [22] studied the effect of coplanar crack angle on the strength and deformation behavior in sandstone samples. The crack initiation and coalescence types containing two coplanar cracks were observed using photographic monitoring from the tips of pre-existing coplanar cracks. As a result of this research a relationship between the coplanar crack angle and the crack coalescence stress was presented. Lee and Jeon [23] applied uniaxial compression test on three different materials to analyze experimentally crack initiation, propagation and coalescence of pre-existing single and double cracks. In addition, the crack initiation and coalescence stresses were investigated in their study showing the crack initiation and propagation depends on the type of material. $\mathrm{Pu}$ and Cao [24] conducted compression tests on rock-like specimens with closed multi-fissures and investigated the influence of fissure inclination angle and distribution density on the breakage characteristics of fissured bodies. 
Various numerical methods have been developed for the simulation of crack propagation in brittle substances, e.g., finite element method (FEM), boundary element method (BEM), discrete element method (DEM), etc.

Three important breakage initiation criteria were proposed to study the crack propagation mechanism of brittle materials: (i) the maximum tangential stress $\left(\sigma_{\theta}\right.$-criterion) [25], (ii) the maximum energy release rate ( $G$-criterion) [26], and (iii) the minimum energy density criterion ( $S$-criterion) [27]. Some modified form of the mentioned criteria, e.g., $F$-criterion which is a modified energy release rate criterion proposed by Shen and Stephansson [28] may also be used to study the breakage behavior of brittle substances [29-31]. Several computer codes were used to model the breakage mechanism in brittle materials such as rocks, i.e., FROCK code [17], rock failure process analysis $\left(\mathrm{RFPA}^{2 \mathrm{D}}\right)$ code [32], 2D particle flow code $\left(\mathrm{PFC}^{2 \mathrm{D}}\right)$ [23].

Single and double cracked specimens (prepared from PCC, fine sand and water) tested under uniaxial compression to study the stress-strain, strength, and crack propagation process in rock-like materials. Some of the experimental works are simulated numerically by a modified higher order displacement discontinuity method and the crack propagation, cracks coalescence are studied based on Mode I and Mode II stress intensity factors (SIFs). The experimental results are compared with the numerical results which confirm each other and illustrate the accuracy and validity of this work.

1. Specimen Preparation and Testing. The cracked rock-like specimens with $60 \mathrm{~mm}$ diameters and $120 \mathrm{~mm}$ lengths are specially prepared from a mixture of portland pozzolana cement (PPC), fine sand, and water.

Table 1 gives the mechanical properties of the rock-like specimens obtained from the laboratory tests.

Various uniaxial compression tests are conducted on rock-like specimens containing either one single crack or two random cracks 1 and 2. These cracks are created by inserting one or two thin steel shims with $10 \mathrm{~mm}$ width and $1 \mathrm{~mm}$ thickness in the mold (before casting the specimens) as shown in Fig. 2.

$\mathrm{T}$ a $\mathrm{b} 1 \mathrm{e} 1$

Some Mechanical Properties of the Rock-Like Specimens

\begin{tabular}{|l|c|}
\hline \multicolumn{1}{|c|}{ Characteristic } & Value \\
\hline Uniaxial compression strength $(\mathrm{MPa})$ & 28 \\
\hline Modulus of elasticity $(\mathrm{GPa})$ & 17 \\
\hline Poisson's ratio & 0.21 \\
\hline Fracture toughness $\left(\mathrm{MPa} \cdot \mathrm{m}^{1 / 2}\right)$ & 2 \\
\hline
\end{tabular}

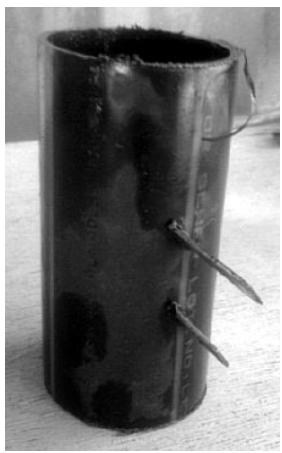

Fig. 2. A typical mold for rock-like specimens.

Some of the specimens have a single center crack oriented at $45^{\circ}$ from the horizontal $x$ axis. The specimens with double cracks are prepared in such a manner that the crack 1 is the same as that of single crack and the crack 2 is oriented at different angles with respect to the direction of crack 1, i.e., at angles $\varphi=0,30,60$, and $90^{\circ}$ (in a counterclockwise direction) as schematically shown in Fig. 3. The uniaxial compressive stress $\sigma$ was uniformly applied and the loading rate was kept at $0.2 \mathrm{MPa} / \mathrm{s}$ during the tests.

Figure 3 demonstrates a schematic view of the geometry of two random cracks (i.e., crack 1 and crack 2) with equal lengths $2 b=10 \mathrm{~mm}$. The locations of cracks are also determined by positions of the crack tips, i.e., tip 1, tip 2, tip 3, and tip 4, respectively.

Therefore, four specimens are prepared each containing two random cracks, 1 and 2, as shown in Fig. 4. 


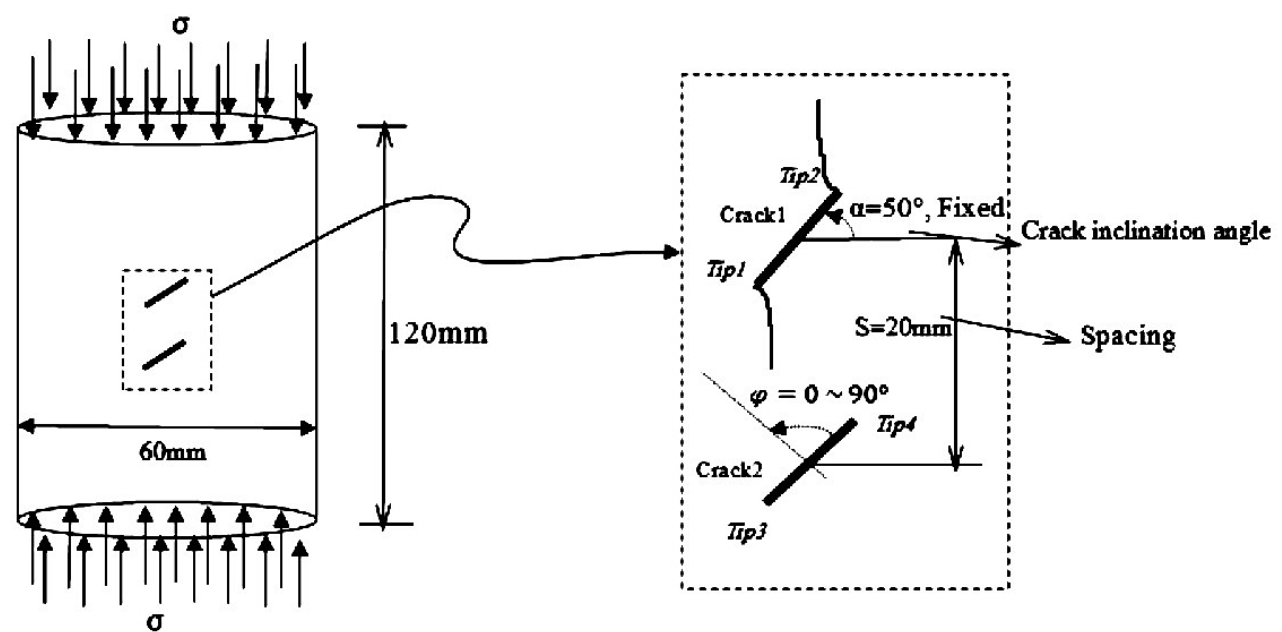

Fig. 3. Geometry of two random cracks in a rock-like specimen under uniaxial compression.

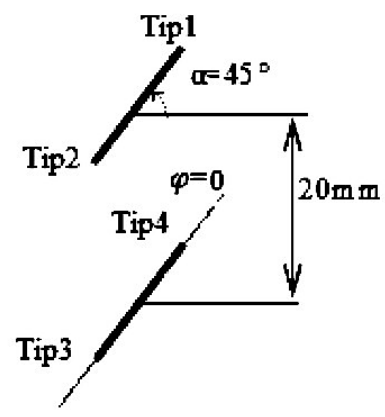

$$
\alpha=45^{\circ}, \varphi=0
$$

a

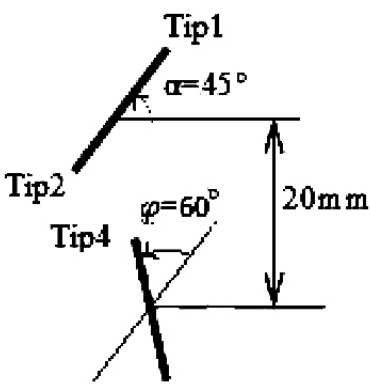

Tip3

$\alpha=45^{\circ}, \varphi=60^{\circ}$

$\mathrm{c}$

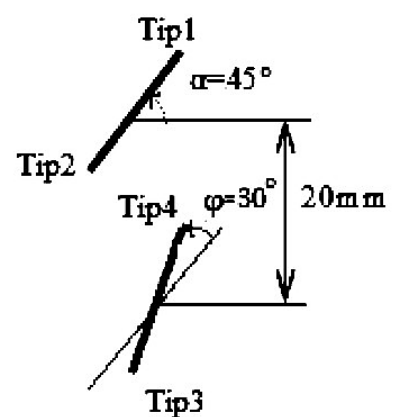

$\alpha=45^{\circ}, \varphi=30^{\circ}$

b

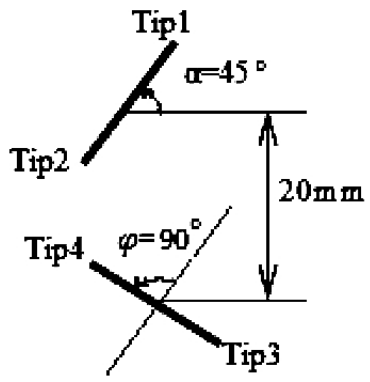

$$
\alpha=45^{\circ}, \varphi=90^{\circ}
$$

d

Fig. 4. Crack geometries with spacing $S=20 \mathrm{~mm}$.

2. Experimental Works and Results. The specially prepared specimens are tested experimentally and the results are used to analyze the stresses and strains of the cracked specimens. The crack propagation process of the specimens considering the cases of (i) single crack and (ii) double cracks are discussed in this section. 
2.1. Stress-Strain Analysis of Cracked Specimens. It is obvious that the cracked rock-like specimens have a lower strength compared to the intact specimens with no crack. The stress strain analysis of the cracked specimens containing one or two cracks with different orientations is of paramount important to study the behavior of the brittle materials. Figure 5 shows the stress strain curve for cracked specimens containing single cracks (inclined $45^{\circ}$ to the horizontal). The initiation and propagation of wing cracks were observed is starting from 14.38 $\mathrm{MPa}$ and ends up at $26.5 \mathrm{MPa}$ where the specimen completely broken away. For the cases of specimens containing two random cracks, the stress strain curve is shown in Fig. 6. The four curves in Fig. 6 are obtained for different orientations of crack 2 with respect to the direction of crack 1 (i.e., for $\varphi=0,30,60$, and $\left.90^{\circ}\right)$.

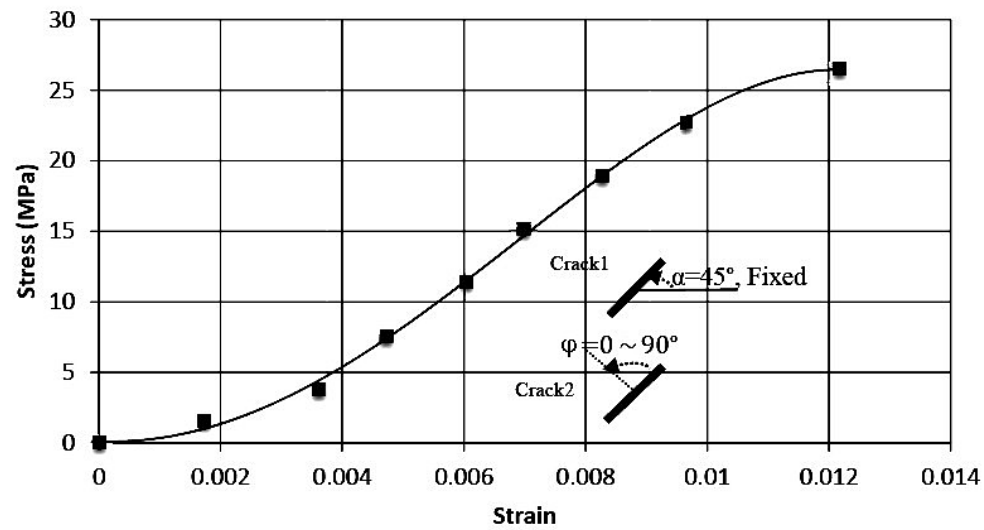

Fig. 5. Stress-strain curve for rock-like specimens containing single crack (crack 1).

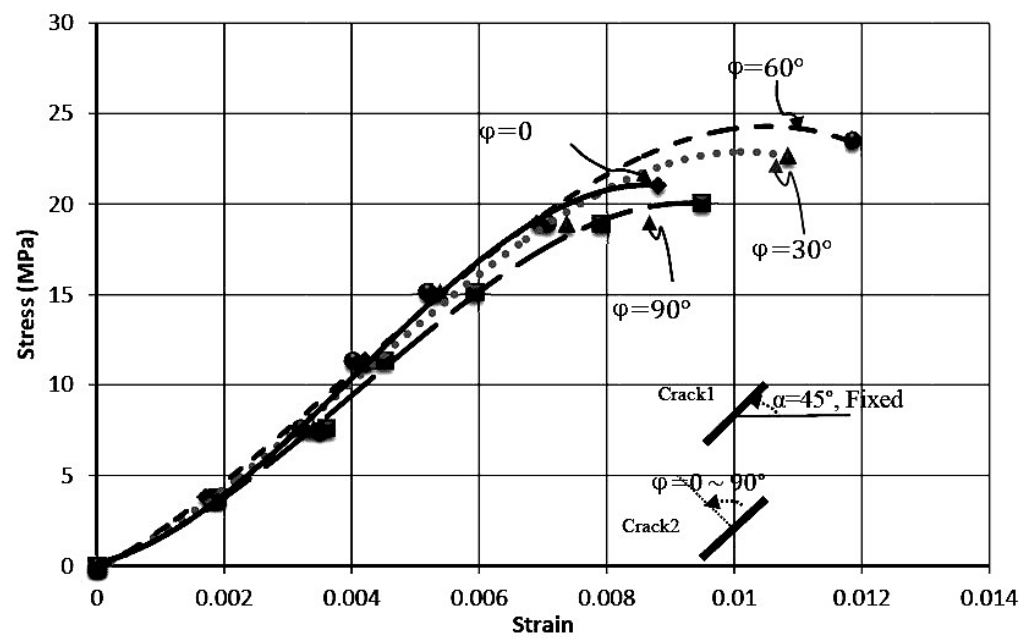

Fig. 6. Stress-strain curve for rock-like specimens containing double cracks.

The stresses causing new crack initiation and the crack coalescence were also observed, respectively (Fig. 7). The ratios of final breakage stress to the uniaxial compressive strength $\left(\sigma_{F} / \sigma_{c}\right)$ for the four cases $\varphi=0,30,60$, and $90^{\circ}$ are given in Fig. 8 . As shown in the Figs. 7 and 8 the stresses of the cracked specimens at different stages of crack propagation process are increasing for $\varphi=0$ to $45^{\circ}$ but decreasing for $\varphi=45^{\circ}$ to $90^{\circ}$, respectively. The lowest value of stress is for the case of perpendicular cracks $\left(\varphi=90^{\circ}\right)$. 


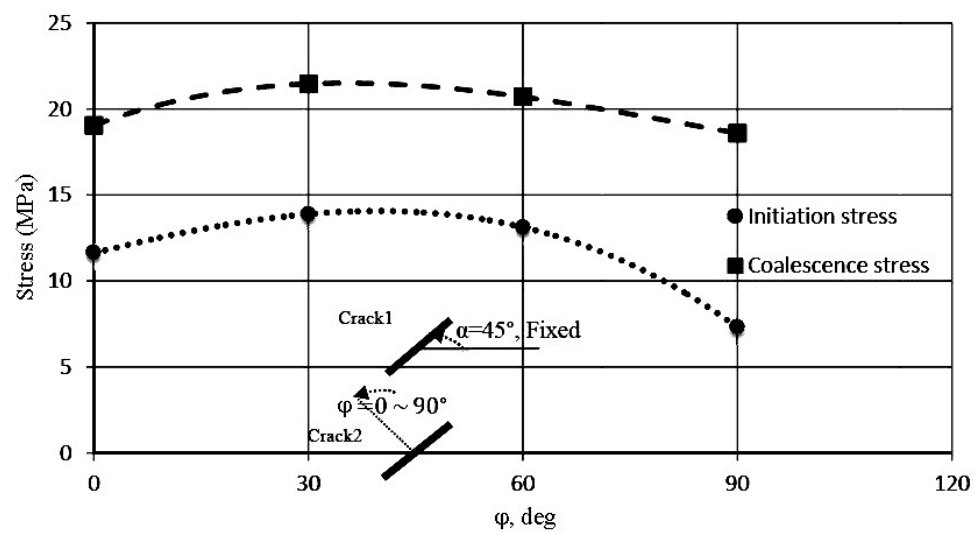

Fig. 7. Stresses of cracks initiation and coalescence process versus different angles of crack 2 with respect to the direction of crack $1\left(\varphi=0,30,60\right.$, and $\left.90^{\circ}\right)$.

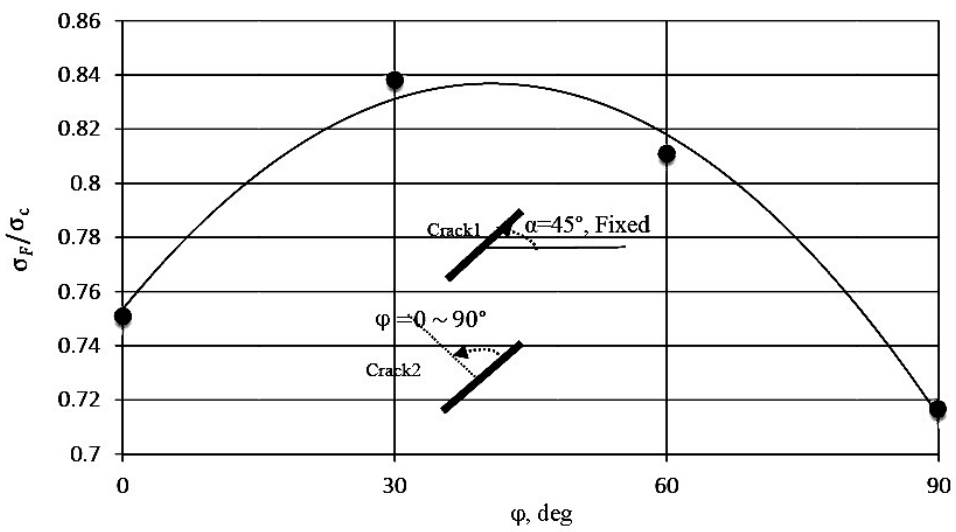

Fig. 8. $\sigma_{F} / \sigma_{c}$ ratios versus $\varphi=0,30,60$, and $90^{\circ}$ (different angles of crack 2 with respect to the direction of crack 1).

\subsection{Crack Propagation Process of Rock-Like Specimens.}

2.2.1. Single Cracked Specimen. Some experimental works have been accomplished to study the mechanism of initiation and propagation of wing and secondary cracks emanating from a single $45^{\circ}$ center slant crack. Figure 9 illustrates the production of wing and secondary cracks originating from the tips of the pre-existing center slant crack. The propagation paths are curved and the wing and secondary cracks are propagating towards the direction of the uniaxial compressive stress applied to the specimen during the experiment. As the load increases the wing cracks propagated further and their aperture increases. The secondary cracks are usually stable cracks propagating after the wing cracks and may be divided into two main types, i.e., (i) quasi-coplanar secondary cracks propagating in the plane of the original crack and (ii) oblique secondary cracks propagating in the plane of wing cracks, i.e., nearly perpendicular to the direction of the original crack.

2.2.2. Double Cracked Specimens. Cracks coalescence phenomenon occurs when the two pre-existing cracks combine due to propagation of wings and/or secondary cracks (originating from the tips of the pre-existing cracks) in brittle substances under various loadings.

In the current experimental works, the wing cracks are instantaneously initiated quasi-statically (Fig. 10). The development and coalescence of wing cracks may be the main cause of the breakage paths in rock-like specimens. Then the secondary cracks may 


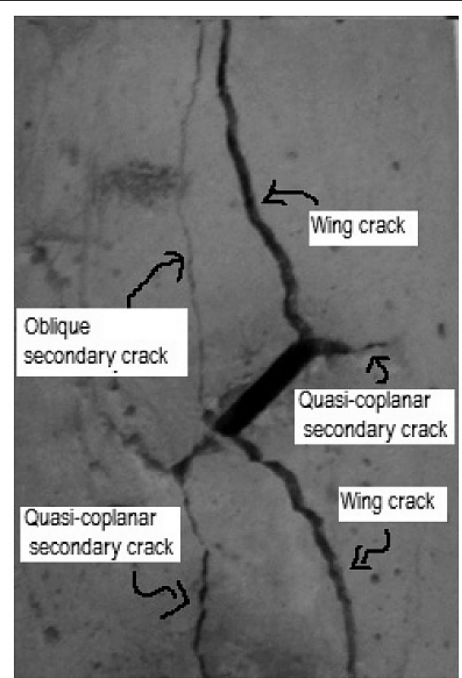

Fig. 9. Cracking pattern in the rock-like specimen considering a single crack (crack 1).

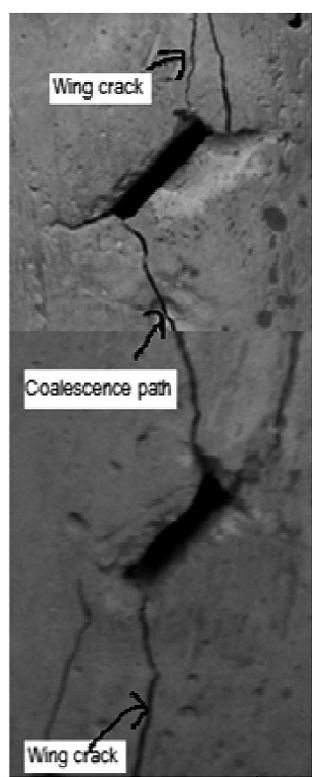

a

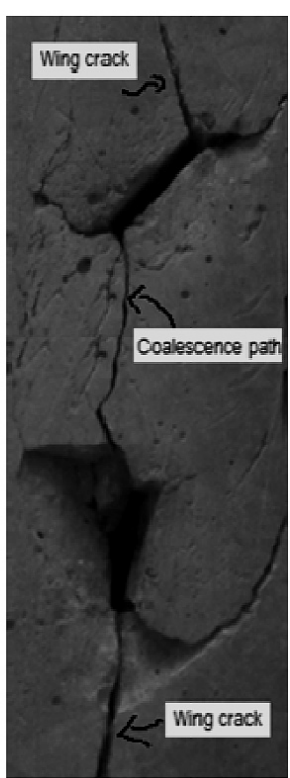

b

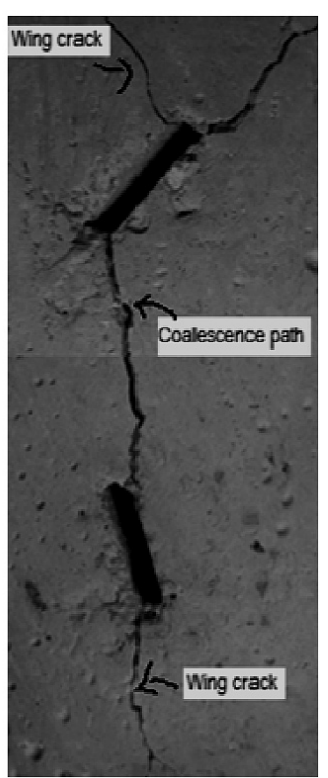

C

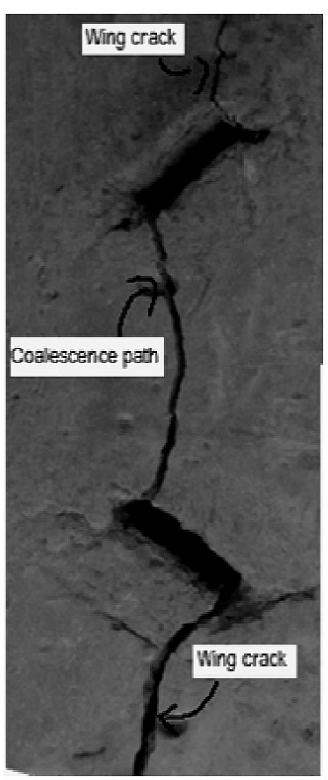

d

Fig. 10. Experimental results illustrating the coalescence path of rock-like specimens containing two cracks: (a) $\alpha=45^{\circ}, \varphi=0$; (b) $\alpha=45^{\circ}, \varphi=30^{\circ}$; (c) $\alpha=45^{\circ}, \varphi=60^{\circ}$; (d) $\alpha=45^{\circ}, \varphi=90^{\circ}$.

be developed and coalesced with the wing cracks in a stable manner. As illustrated in Fig. 10, the experimental tests, demonstrate that the secondary cracks may not always be observed, but the wing cracks are appeared instantaneously. Wing cracks may start their initiation at stress levels of about one half of the specimen's strength. Otherwise, the secondary cracks are approximately occurred near the peak strength of the specimens, and may extend in an unstable manner.

Figure 10a-d shows the observed wing cracks propagating toward each other and causing crack coalescence. Figure 10a-d illustrates four cases of coalescence paths due to the propagation of the wing cracks that are observed in the experiments. 


\section{Numerical Simulation.}

3.1. Displacement Discontinuity Method. A displacement based version of the indirect boundary element method known as displacement discontinuity method (DDM) originally proposed by Crouch [33] for the solution of elastostatic problems in solid mechanics is used in this study [34-38].

In this research, a higher accuracy of the displacement discontinuities along the boundary of the problem is obtained by using quadratic displacement discontinuity (DD) elements is used. A quadratic DD element is divided into three equal sub-elements that each sub-element contains a central node for which the nodal DD is evaluated numerically [29-30].

3.2. Numerical Simulation of the Cracked Specimens. A modified higher order displacement discontinuity method based on the versatile boundary element method [37] is used for the numerical simulation of the experimental works proposed in this research to study the cracks coalescence and crack propagation process of brittle substances under compressive loading conditions. The four different specimens already shown in Fig. 10a-d are simulated numerically by the proposed numerical method and the results are shown graphically in Fig. 11a-d. The linear elastic fracture mechanics (LEFM) approach based on the concept of Mode I and Mode II stress intensity factors (SIFs) proposed by Irwin [39] is implemented in the boundary element code and the maximum tangential stress criterion given by Erdogan and Sih [25] is used in a stepwise procedures (15 steps) to estimate the propagation path of the propagating wing cracks. The simulated propagation paths are in good agreement with corresponding experimental results shown in Fig. 10.

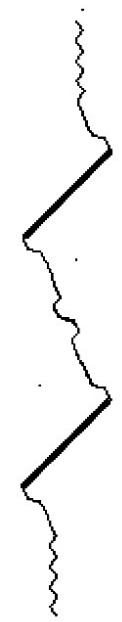

a

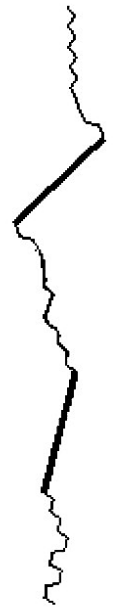

b

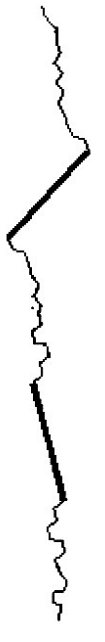

c

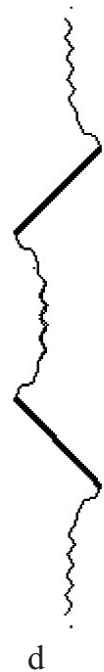

d

Fig. 11. Numerical simulation of crack coalescence path for specimens containing two cracks: (a) $\alpha=$ $=45^{\circ}, \varphi=0$; (b) $\alpha=45^{\circ}, \varphi=30^{\circ}$; (c) $\alpha=45^{\circ}, \varphi=60^{\circ}$; (d) $\alpha=45^{\circ}, \varphi=90^{\circ}$.

Since the experimental analysis of crack propagation is somewhat time-consuming, expensive, difficult and complex, in this study, some more numerical simulations of crack propagation process are also accomplished by boundary element method.

As experimentally shown in the previous section, the crack inclination angle in rock-like specimens has a significant effect on their final breakage.

In the experimental work, the inclination angle of crack $1, \alpha_{2}$, in the last molding was $45^{\circ}$. The numerical simulation is done for two cases with $\alpha=0$ and $90^{\circ}$ (horizontal and vertical) in which the crack 2 is oriented at different angles with respect to the direction of crack 1 (i.e., at angles $\varphi=0,30,60$, and $90^{\circ}$ ) as schematically shown in Fig. 12. 


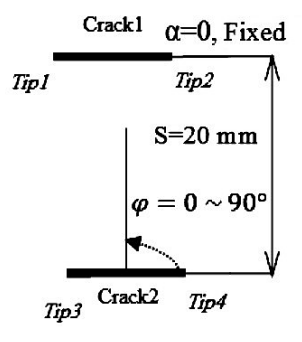

a

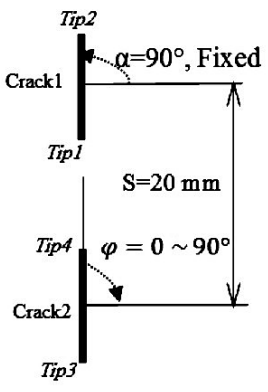

b

Fig. 12. Geometry of two random cracks considering: (a) crack 1 with horizontal orientation $(\alpha=0)$; (b) crack 1 with vertical orientation $\left(\alpha=90^{\circ}\right)$.

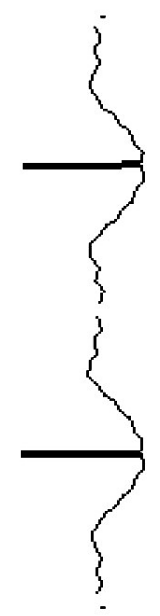

a

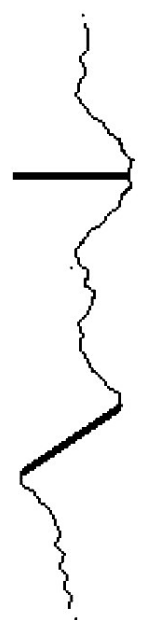

b

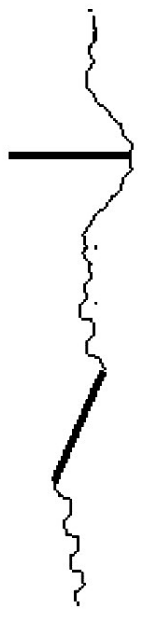

c

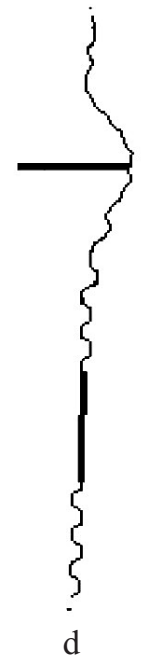

d

Fig. 13. Numerical simulation of crack coalescence path for specimens containing two cracks: (a) $\alpha=$ $=0, \varphi=0$; (b) $\alpha=0, \varphi=30^{\circ}$; (c) $\alpha=0, \varphi=60^{\circ}$; (d) $\alpha=0, \varphi=90^{\circ}$.

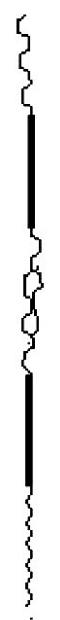

a

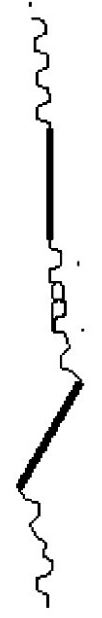

b

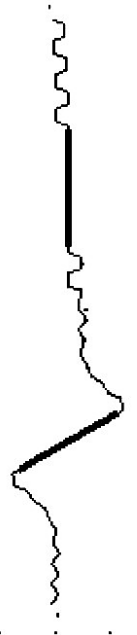

c

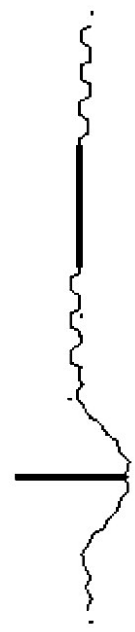

d

Fig. 14. Numerical simulation of crack coalescence path for specimens containing two cracks: (a) $\alpha=$ $=90^{\circ}, \varphi=0$; (b) $\alpha=90^{\circ}, \varphi=30^{\circ}$; (c) $\alpha=90^{\circ}, \varphi=60^{\circ}$; (d) $\alpha=90^{\circ}, \varphi=90^{\circ}$. 
Figures 13 and 14 present the results of numerical simulation considering different inclination angles of crack 2 (i.e., at angles $\varphi=0,30,60$, and $90^{\circ}$ ). Comparing Figs. 12 14 , it can be concluded that the final breakage path of the pre-cracked specimens may be affected by crack orientation.

3.3. Effects of Cracks Orientation on the SIFs. The Mode I stress intensity, $K_{\mathrm{I}}$, and Mode II stress intensity factor, $K_{\text {II }}$, can be normalized as

$$
\begin{aligned}
& K_{\mathrm{I}}^{N}=\frac{K_{\mathrm{I}}}{\sigma \sqrt{\pi b}}, \\
& K_{\mathrm{II}}^{N}=\frac{K_{\mathrm{II}}}{\sigma \sqrt{\pi b}},
\end{aligned}
$$

the numerical values of the normalized SIFs, $K_{\mathrm{I}}^{N}$ and $K_{\mathrm{II}}^{N}$ near the original tips of two random cracks are numerically estimated by considering crack 1 with constant inclination angles, $\alpha=0,45$, and $90^{\circ}$ and crack 2 at different $\varphi$ angles with respect to the direction of crack 1 (i.e., at angles, $\varphi=0,30,60$, and $90^{\circ}$ ). The values of $K_{\mathrm{I}}^{N}$ and $K_{\mathrm{II}}^{N}$ are obtained for the first step of crack propagation process. Table 2 presents the values of $K_{\mathrm{I}}^{N}$ and $K_{\mathrm{II}}^{N}$ at the four tips of the two pre-existing cracks (shown in Figs. 3 and 12).

$\mathrm{T}$ a b 1 e 2

Numerical Values of $K_{\mathrm{I}}^{N}$ and $K_{\mathrm{II}}^{N}$ for the Four Crack Tips of Two Pre-Existing Cracks (Considering Constant Inclination Angles $\alpha=\mathbf{0 , 4 5}$, and $\mathbf{9 0}^{\circ}$ and Crack 2

\begin{tabular}{|c|c|c|c|c|c|c|c|c|c|}
\hline \multirow{2}{*}{\multicolumn{2}{|c|}{$\begin{array}{l}\text { Crack inclination } \\
\text { angle }\end{array}$}} & \multicolumn{4}{|c|}{$K_{\mathrm{I}}^{N}$} & \multicolumn{4}{|c|}{$K_{\mathrm{II}}^{N}$} \\
\hline & & \multirow{2}{*}{$\begin{array}{c}\text { Tip } 1 \\
1.0173\end{array}$} & \multirow{2}{*}{\begin{tabular}{|c|} 
Tip 2 \\
1.0173
\end{tabular}} & \multirow{2}{*}{$\begin{array}{c}\text { Tip } 3 \\
-\end{array}$} & \multirow{2}{*}{$\frac{\text { Tip } 4}{-}$} & \multirow{2}{*}{$\begin{array}{c}\text { Tip } 1 \\
0\end{array}$} & \multirow{2}{*}{\begin{tabular}{|c|} 
Tip 2 \\
0
\end{tabular}} & \multirow{2}{*}{$\begin{array}{c}\text { Tip } 3 \\
-\end{array}$} & \multirow{2}{*}{$\begin{array}{c}\text { Tip } 4 \\
-\end{array}$} \\
\hline$\alpha=0$ & $\begin{array}{c}\text { Crack } 1 \\
\text { (single crack) }\end{array}$ & & & & & & & & \\
\hline & $\varphi=0$ & 0.9535 & 0.9534 & 0.9575 & 0.9575 & 0.0148 & 0.0167 & 0.0155 & 0.0177 \\
\hline & $\varphi=30^{\circ}$ & 0.9616 & 0.9741 & 0.7351 & 0.6970 & 0.0028 & 0.0233 & 0.3983 & 0.4070 \\
\hline & $\varphi=60^{\circ}$ & 0.9922 & 1.0080 & 0.2628 & 0.2400 & 0.0067 & 0.0167 & 0.4040 & 0.3754 \\
\hline & $\varphi=90^{\circ}$ & 1.0181 & 1.0180 & 0.0267 & 0.0374 & 0 & 0 & 0.0011 & 0.0021 \\
\hline \multirow[t]{5}{*}{$\alpha=45^{\circ}$} & $\begin{array}{c}\text { Crack } 1 \\
\text { (single crack) }\end{array}$ & 0.5106 & 0.5106 & - & - & 0.5063 & 0.5063 & - & - \\
\hline & $\varphi=0$ & 0.4945 & 0.5188 & 0.5223 & 0.4977 & 0.4691 & 0.4860 & 0.4872 & 0.4713 \\
\hline & $\varphi=30^{\circ}$ & 0.5145 & 0.5189 & 0.0888 & 0.0924 & 0.4965 & 0.5043 & 0.2557 & 0.2448 \\
\hline & $\varphi=60^{\circ}$ & 0.5004 & 0.5025 & 0.0747 & 0.0709 & 0.5061 & 0.5017 & 0.2308 & 0.2136 \\
\hline & $\varphi=90^{\circ}$ & 0.4324 & 0.4408 & 0.5357 & 0.5078 & 0.5047 & 0.5018 & 0.5137 & 0.5161 \\
\hline \multirow[t]{5}{*}{$\alpha=90^{\circ}$} & $\begin{array}{c}\text { Crack } 1 \\
\text { (single crack) }\end{array}$ & 0.0007 & 0.0007 & - & - & 0 & 0 & - & - \\
\hline & $\varphi=0$ & 0.0008 & 0.0008 & 0.0025 & 0.0018 & 0 & 0 & 0 & 0 \\
\hline & $\varphi=30^{\circ}$ & 0.0125 & 0.0078 & 0.2585 & 0.2582 & 0.0200 & 0.0131 & 0.4392 & 0.4393 \\
\hline & $\varphi=60^{\circ}$ & 0.0289 & 0.0191 & 0.7682 & 0.7675 & 0.0147 & 0.0109 & 0.4382 & 0.4382 \\
\hline & $\varphi=90^{\circ}$ & 0.0352 & 0.0239 & 1.0221 & 1.0221 & 0.0021 & 0.0010 & 0.0004 & 0.0003 \\
\hline
\end{tabular}
with Different Angles $\varphi=0,30,60$, and $90^{\circ}$ ) 


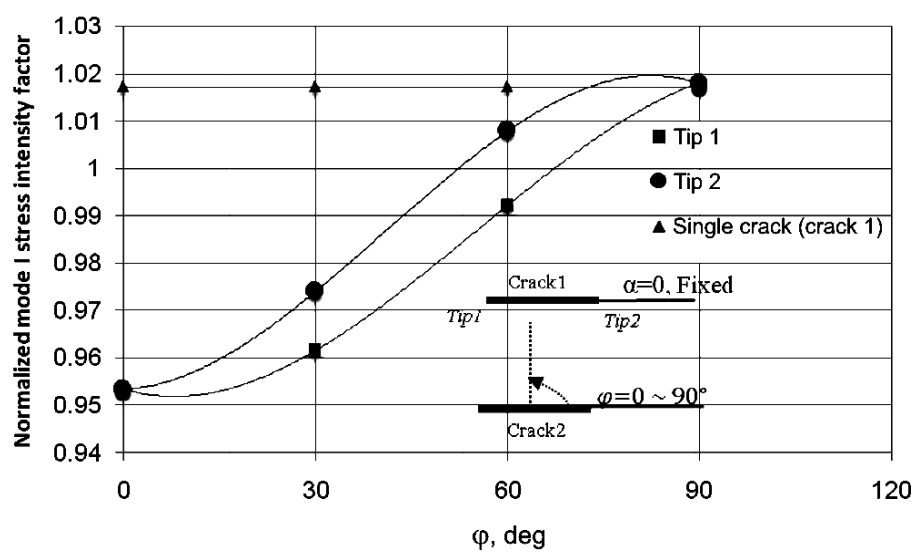

Fig. 15. Behavior of $K_{\mathrm{I}}^{N}$ versus the changes of $\varphi$ angles with a constant inclination angle $\alpha=0$.

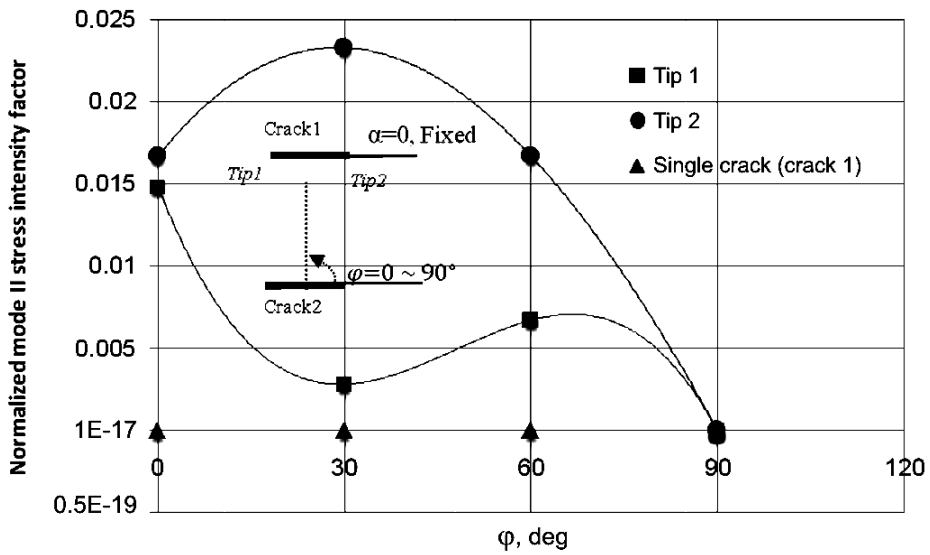

Fig. 16. Behavior of $K_{\mathrm{II}}^{N}$ versus the changes of $\varphi$ angles with a constant inclination angle $\alpha=0$.

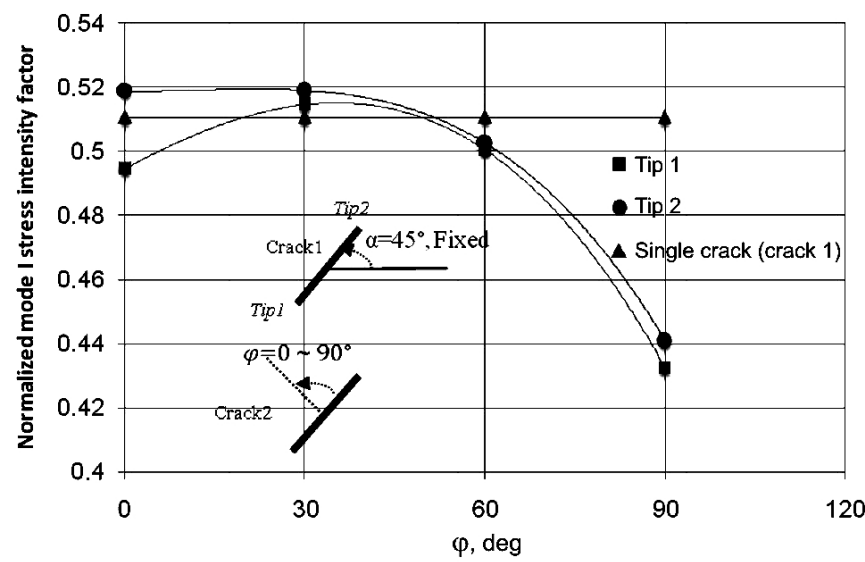

Fig. 17. Behavior of $K_{\mathrm{I}}^{N}$ versus the changes of $\varphi$ angles with a constant inclination angle $\alpha=45^{\circ}$.

The interaction between the two pre-existing cracks may cause some changes in the values of the normalized SIFs (at different locations of the cracks).

Therefore, it can be concluded that interaction of the normalized SIFs may be a significant factor in estimating the initiation, propagation and coalescence of cracks 


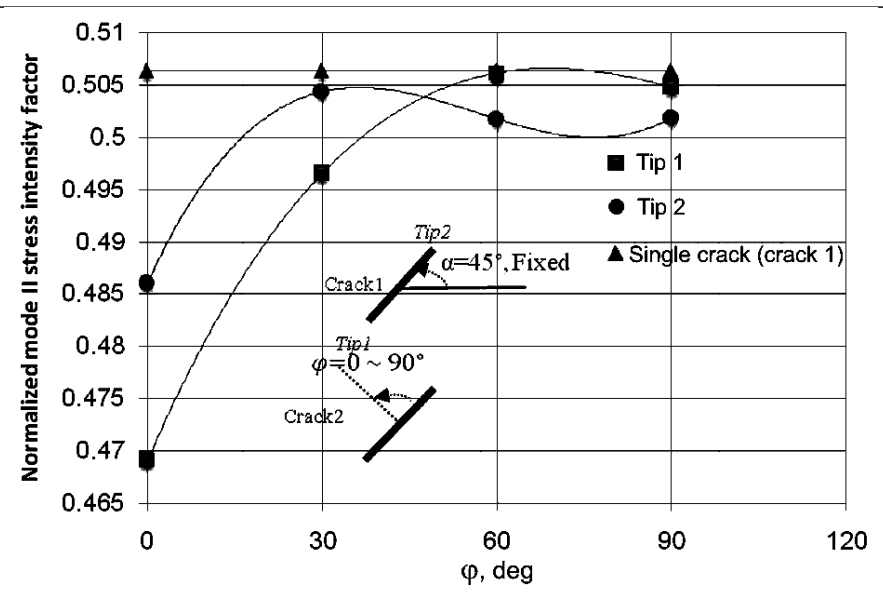

Fig. 18. Behavior of $K_{\mathrm{II}}^{N}$ versus the changes of $\varphi$ angles with a constant inclination angle $\alpha=45^{\circ}$.

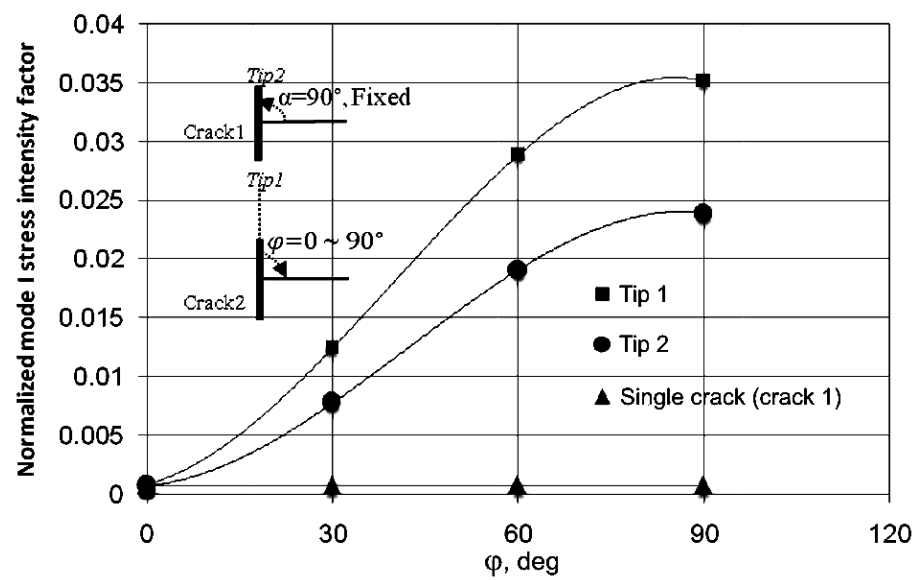

Fig. 19 Behavior of $K_{\mathrm{I}}^{N}$ versus the changes of $\varphi$ angles with a constant inclination angle $\alpha=90^{\circ}$.

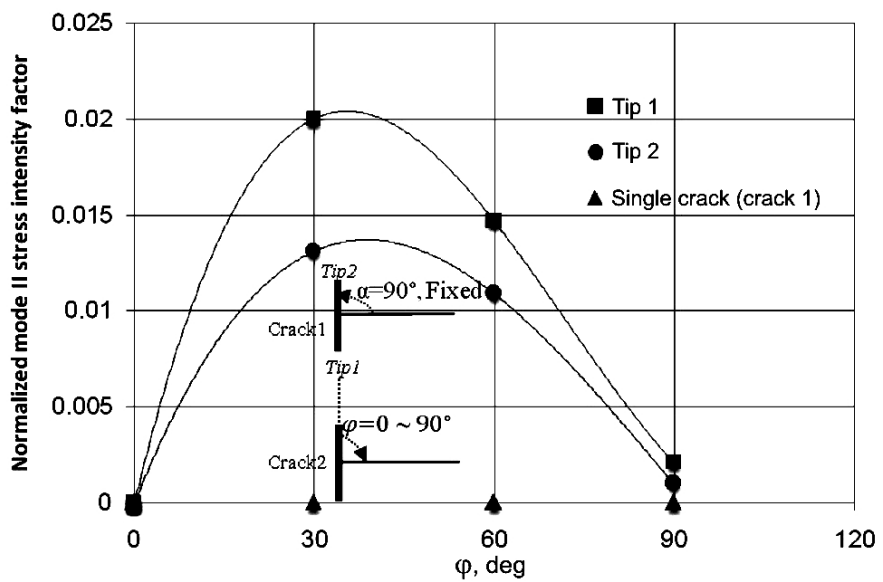

Fig. 20. Behavior of $K_{\mathrm{II}}^{N}$ versus the changes of $\varphi$ angles with a constant inclination angle $\alpha=90^{\circ}$.

propagating from the tips of pre-existing cracks, and also this interaction may strongly depends on the positions of the cracks. 
To demonstrate the effect of the second crack (crack 2) on the cracks coalescence and crack propagation paths, the numerical values of $K_{\mathrm{I}}^{N}$ and $K_{\mathrm{II}}^{N}$ for the first crack (crack 1 ) in the absence of the second crack (crack 2), i.e., for a single crack are also shown in Figs. 15-20, respectively.

These numerical results show that the final crack propagation paths may strongly depend on the inclination of crack 2 (as shown in Table 2 and Figs. 15-20).

Conclusions. Crack propagation mechanism of brittle substances has been studied in comprehensive experimental and numerical works in the recent years. It is a complicated process and further research may be devoted to investigate the crack propagation, crack coalescence and final breakage paths of the rocks and rock-like materials under compression. In this research, a detailed analysis of the fracturing process of the pre-cracked rock-like material has been accomplished by experimental tests and numerical simulation. Effects of fracturing on the strength and stress-strain curves of the pre-cracked rock-like materials have been discussed. It has been shown that the crack propagation mechanism in brittle substances due to the cracks coalescence phenomenon occur mainly by propagation of wing cracks emanating from the tips of the pre-existing cracks. The secondary cracks may also be produced after the propagation of the wing cracks in the specimens under uniaxial loadings but it is experimentally shown that the wing cracks are mainly responsible for the cracks coalescence and the final cracks propagating paths. The same experimental specimens are modeled numerically by an indirect boundary element method and the corresponding numerical results are in good agreement with the experimental results. The experimental and numerical models illustrate well the generation of the wing and secondary cracks, as well as the cracks propagation paths produced by the coalescence phenomenon of the two pre-existing cracks. The effects of the stress ratio and orientation of the second crack on the propagation path and cracks' coalescence have also been studied numerically in this research.

\section{Р ез юм е}

Проведено випробування на стиск циліндричних зразків із початковими тріщинами 3 матеріалу типу гірських порід (пуцолановий портландцемент). Результати експериментальних вимірювань напруги, деформацій і характеристик міцності зразків показують, що наявність початкових тріщин і їх орієнтація не мають значного впливу на величину границі міцності при стисканні. Досліджено зародження і злиття тріщин на стадії їх росту. Процес руйнування зразків досліджували для випадків наявності в їхній центральній частині одиночних або парних тріщин, що розташовані під різними кутами, і прикладення одновісного стискального навантаження до обох торців зразка. На першій стадії навантаження відмічалось виникнення стрілоподібних тріщин і їх ріст у напрямку осі одновісного стискального навантаження. Окрім того, вторинні тріщини 3 квазикомпланарною і (або) похилою конфігурацією характеризуються стабільним ростом. У подальшому ці тріщини можуть розвиватися у напрямку максимальних головних напружень. Виконано числовий розрахунок зразків із тріщинами за допомогою непрямого методу граничних елементів, тобто: методу розриву переміщень. Порівняльний аналіз розрахункових і експериментальних результатів підтверджує їх вірогідність.

1. A. R. Ingraffea, "Fracture propagation in rock," in: Z. P. Bazant (Ed.), Mechanics of Geomaterials: Rocks, Concretes, Soils, Ch. 12, John Wiley \& Sons, Chichester, New York (1985), pp. 219-258.

2. H. Horii and S. Nemat-Nasser, Compression-induced microcrack growth in brittle solids: Axial splitting and shear failure, J. Geophys. Res., 90, 3105-3125 (1985). 
3. O. Reyes and H. H. Einstein, "Failure mechanism of fractured rock - a fracture coalescence model," in: Proc. 7th Int. Congress of Rock Mechanics, Vol. 1 (1990), pp. 333-340.

4. B. Shen, O. Stephansson, H. H. Einstein, and B. Ghahreman, "Coalescence of fractures under shear stress experiments," J. Geophys. Res., 100, 5975-5990 (1995).

5. R. H. C. Wong and K. T. Chau, "Crack coalescence in a rock-like material containing two cracks," Int. J. Rock Mech. Min. Sci., 35, 147-164 (1998).

6. C. C. Ke, C. S. Chen, and C. H. Tu, "Determination of fracture toughness of anisotropic rocks by boundary element method," Rock Mech. Rock Eng., 41, 509-538 (2008).

7. E. Hoek and Z. T. Bieniawski, "Brittle rock fracture propagation in rock under compression," Int. J. Fract. Mech., 1, 137-155 (1965).

8. Z. T. Bieniawski, "Mechanism of brittle fracture of rock. Pt. II. Experimental studies," Int. J. Rock Mech. Min. Sci. Geomech. Abstr., 4, 407-23(1967).

9. A. Bobet and H. H. Einstein, "Fracture coalescence in rock-type materials under uniaxial and biaxial compression," Int. J. Rock Mech. Min. Sci., 35, 863-888 (1998).

10. A. Bobet and H. H. Einstein, "Numerical modeling of fracture coalescence in a model rock material," Int. J. Fract., 92, 221-252 (1998).

11. J. F. Huang, G. L. Chen, Y. H. Zhao, and R. Wang, "An experimental study of the strain field development prior to failure of a marble plate under compression," Tectonophysics, 175, 269-284 (1990).

12. R. H. C. Wong, K. T. Chau, C. A. Tang, and P. Lin, "Analysis of crack coalescence in rock-like materials containing three flaws - Part I: experimental approach," Int. J. Rock Mech. Min. Sci., 38, 909-924 (2001).

13. E. Sahouryeh, A. V. Dyskin, and L. N. Germanovich, "Crack growth under biaxial compression," Eng. Fract. Mech., 69, 2187-2198 (2002).

14. Y. P. Li, L. Z. Chen, and Y. H. Wang, "Experimental research on pre-cracked marble under compression," Int. J. Solids Struct., 42, 2505-2516 (2005).

15. C. H. Park and A. Bobet, "The initiation of slip on frictional fractures," in: 41st US Rock Mechanics Symposium, Paper 06-923, Golden, CO (2006).

16. C. H. Park and A. Bobet, "Crack initiation and propagation from frictional fractures," in: Proc. of the 1st Canada-US Rock Mechanics Symposium (2007), pp. 557-564.

17. C. H. Park, Coalescence of Frictional Fractures in Rock Materials, Ph.D. Thesis, Purdue University, West Lafayette, IN (2008).

18. C. H. Park and A. Bobet, "Crack coalescence in specimens with open and closed flaws: A comparison," Int. J. Rock Mech. Min. Sci., 46, 819-829 (2009).

19. C. H. Park and A. Bobet, "Crack initiation, propagation and coalescence from frictional flaws in uniaxial compression," Eng. Fract. Mech., 77, 2727-2748 (2010).

20. S. Q. Yang, Y. H. Dai, L. J. Han, and Z. Q. Jin, "Experimental study on mechanical behavior of brittle marble samples containing different flaws under uniaxial compression," Eng. Fract. Mech., 76, 1833-1845 (2009).

21. R. P. Janeiro and H. H. Einstein, "Experimental study of the cracking behavior of specimens containing inclusions (under uniaxial compression)," Int. J. Fract., 164, 83-102 (2010).

22. S. Q. Yang, "Crack coalescence behavior of brittle sandstone samples containing two coplanar fissures in the process of deformation failure," Eng. Fract. Mech., 78, 3059-3081 (2011). 
23. H. Lee and S. Jeon, "An experimental and numerical study of fracture coalescence in pre-cracked specimens under uniaxial compression," Int. J. Solids Struct., 48, 979999 (2011).

24. C. Pu and P. Cao, "Failure characteristics and its influencing factors of rock-like material with multi-fissures under uniaxial compression," Trans. Nonferrous Met. Soc. China, 22, 185-191 (2012).

25. F. Erdogan and G. C. Sih, "On the crack extension in plates under loading and transverse shear," J. Basic Eng., 85, Issue 4, 519-525 (1963).

26. M. A. Hussian, E. L. Pu, and J. H. Underwood, "Strain energy release rate for a crack under combined mode I and mode II," in: Fracture Analysis, ASTM STP 560, Philadelphia, PA (1974), pp. 2-28.

27. G. C. Sih, "Strain-energy-density factor applied to mixed mode crack problems," Int. J. Fract., 10, 305-321 (1974).

28. B. Shen and O. Stephansson, "Modification of the G-criterion for crack propagation subjected to compression," Eng. Fract. Mech., 47, 177-189 (1994).

29. M. F. Marji, H. Hosseini Nasab, and A. H. Kohsary, "On the uses of special crack tip elements in numerical rock fracture mechanics," Int. J. Solids Struct., 43, Issue 6, 1669-1692 (2006).

30. M. F. Marji and I. Dehghani, "Kinked crack analysis by a hybridized boundary element/ boundary collocation method," Int. J. Solids Struct., 47, Issue 7-8, 922-933 (2010).

31. M. F. Marji, "On the use of power series solution method in the crack analysis of brittle materials by indirect boundary element method," Eng. Fract. Mech., 98, 365-382 (2013).

32. R. H. C. Wong, C. A. Tang, K. T. Chau, and P. Lin, "Splitting failure in brittle rocks containing pre-existing flaws under uniaxial compression," Eng. Fract. Mech., 69, 1853-1871 (2002).

33. S. L. Crouch, Analysis of Stresses and Displacements around Underground Excavations: An Application of the Displacement Discontinuity Method, Geomechanics Report, University of Minnesota, Minneapolis, MN (1976).

34. H. Guo, N. I. Aziz, and R. A. Schmidt, "Linear elastic crack tip modeling by displacement discontinuity method," Eng. Fract. Mech., 36, 933-943 (1990).

35. C. Scavia, "Fracture mechanics approach to stability analysis of crack slopes," Eng. Fract. Mech., 35, 889-910 (1990).

36. M. H. Aliabadi and D. P. Rooke, Numerical Fracture Mechanics, Computational Mechanics Publications, Southampton, UK (1991).

37. H. Haeri, Numerical Modeling of the Interaction between Micro and Macro Cracks in the Rock Fracture Mechanism Using Displacement Discontinuity Method, Ph.D. Thesis, Department of Mining Engineering, Science and Research Branch, Islamic Azad University, Tehran, Iran (2011).

38. H. Haeri and A. K. Ahranjani, "A fuzzy logic model to predict crack propagation angle under disc cutters of TBM," Int. J. Acad. Res., 4, No. 3, 159-169 (2012).

39. G. R. Irwin, "Analysis of stress and strains near the end of a crack traversing a plate," J. Appl. Mech., 24, 361-364 (1957). 